\title{
Reducing COD Level on Oily Effluent by Utilizing Biosurfactant-Producing Bacteria
}

\author{
Daniela Franco Carvalho Jacobucci ${ }^{1 *}$, Maria Raquel de Godoy Oriani ${ }^{2}$ and Lucia Regina \\ Durrant $^{3}$ \\ ${ }^{l}$ Instituto de Biologia; Universidade Federal de Uberlândia; 38400-902; Uberlândia - MG - Brasil. ${ }^{2}$ Centro \\ Universitário da Fundação de Ensino Octávio Bastos; 13870-159; São João da Boa Vista - SP - Brasil. \\ ${ }^{3}$ Departamento de Ciência de Alimentos; Universidade Estadual de Campinas; C. P.:6121; 13081-970; Campinas - \\ SP - Brasil
}

\begin{abstract}
Two bacteria isolated from crude oil contaminated soil, Pantoea agglomerans and Planococcus citreus, produced biosurfactants utilizing $1.5 \%$ of kerosene and olive oil as the sole carbon sources, respectively. The bacteria and the biosurfactants produced were introduced to oily effluent, arising from margarine and soap industry. Emulsification activities were determined by increases in the absorbance of the oil-in-water emulsions at $610 \mathrm{~nm}$, whereas the water-in-oil emulsions were expressed as the height $(\mathrm{cm})$ of the emulsion layers formed. The $72 \mathrm{~h}$ incubation experiment resulted in a COD (Chemical Oxygen Demand) reduction of $76 \%$ with Planococcus citreus strain and $70 \%$ with Pantoea agglomerans.The COD reduction with bacterial biosurfactants was over $50 \%$ in $24 h$ of incubation. The COD reduction showed that these strains and the surfactants produced could be used in bioremediation processes.
\end{abstract}

Key words: Biosurfactants, bacteria, COD, oily effluent, bioremediation

\section{INTRODUCTION}

Surface-active compounds from biological origin (biosurfactants) have received increasing attention in recent years because of their role in the growth of microorganisms on water-insoluble, hydrophobic materials such as hydrocarbons and other lipophilic substrates. The biosurfactants are a diverse group of bio-molecules which share the same properties as synthetic surfactants, and in some cases, they are superior in creating water-in-oil or oil-in-water emulsions (Ashtaputre and Shah, 1995).

Microbial derived surfactants have special advantages over their chemically manufactured counterparts because of their lower toxicity, biodegradable nature and effectiveness at extreme temperature and $\mathrm{pH}$ values (Pruthi and Cameotra, 1997). Biosynthesis and excretion of biosurfactants into the medium are considered to be a mechanism of the microbial metabolism for using external lipophilic compounds as carbon and energy sources.

When properly stimulated, biosurfactant-producing microorganisms can aid in the bioremediation of oil-contaminated soil, of hydrocarbon contaminants in the environment, and can also stimulate the

\footnotetext{
* Author for correspondence: danielafcj@inbio.ufu.br
} 
biodegradation of fats and oils present in wastewater produced by various food industries (Carrillo et al., 1996).

Deleu and Paquot (2004) presented a review about the importance of surfactants emphasizing the following functional properties: detergency, oil-inwater emulsification, water-in-oil emulsification, foaming solubilization and oil dispersion. Since surfactants are frequently used as emulsifiers, the emulsion classification during the emulsification process is important, because oil-in-water $(\mathrm{o} / \mathrm{w})$ and water-in-oil (w/o) emulsions have different properties and applications.

The Chemical Oxygen Demand (COD) and Biochemical Oxygen Demand (BOD) are indirect parameters to determine the pollution of industrial effluents. Treatments that could contribute to decrease COD or BOD values are of special interest to industries (Von Sperlins, 1996).

The purpose of this study was to develop a practical way to analyze the use of bacteria and biosurfactants to bioremediate margarine and soap industry oily effluent. The emulsification activities in culture broth were determined by observing what types of emulsions were stimulated by bacterial surfactants: oil-in-water or water-in-oil emulsions. Experiments involving bacteria and bacterial biosurfactant addition to the oily effluent were carried out to evaluate the Chemical Oxygen Demand (COD) reduction and modifications in total solids and $\mathrm{pH}$.

\section{MATERIALS AND METHODS}

\section{Isolation and maintenance of bacterial strains}

Two bacterial strains were isolated and selected in previous works (Durrant et al., 1999; Jacobucci et al., 2001) from soil contaminated with crude oil near Paulinia's petroleum refinery in Campinas (São Paulo State, Brazil). They were identified as Pantoea agglomerans ( Gram-negative bacilli) and Planococcus citreus (Gram-positive coccus) by biochemical tests and observation of all morphological characteristics (Holt et al., 1994). Pantoea agglomerans was maintained in Nutrient Agar (NA) and Planococcus citreus in YPD agar, both DIFCO medium, at $30^{\circ} \mathrm{C}$.

\section{Biosurfactants production and isolation}

Pantoea agglomerans and Planococcus citreus were cultivated in a medium containing $1.5 \%(\mathrm{v} / \mathrm{v})$ of kerosene and olive oil, respectively, plus $0.5 \mathrm{~g}$ $\mathrm{MgSO}_{4}, 3.0 \mathrm{~g} \mathrm{NaNO}_{3}, 1.0 \mathrm{~g} \mathrm{KH}_{2} \mathrm{PO}_{4}, 1.0$ g yeast extract and $0.3 \mathrm{~g}$ peptone per liter of medium (Rapp and Backhaus, 1992). Cultures were grown in 500 $\mathrm{ml}$ Erlenmeyer flasks with $300 \mathrm{ml}$ of medium and incubated at $30^{\circ} \mathrm{C}$ in a rotatory shaker $(150 \mathrm{rpm})$ for $48 \mathrm{~h}$. Culture broth was centrifugated at 9,000 rpm during 15 minutes, and the supernatant was used to isolate the biosurfactants and measurement of emulsions stability. Pantoea agglomerans culture broth was vigorously mixed in separation funnel with chloroform and methanol $(3: 2: 1, \quad \mathrm{v} / \mathrm{v} / \mathrm{v})$ and Planococcus citreus culture broth with chloroform $(3: 2, \mathrm{v} / \mathrm{v})$. The foam formed on the surface part of each culture broth was collected and the residual solvent was eliminated by rotoevaporation. The isolated biosurfactant was lyophilized and stored at ambient temperature in a desiccator (modified from Rocha et al., 1992). The lyophilized biosurfactant was weighed and the biosurfactant production was expressed in grams per liter of culture broth.

\section{Emulsion stabilized measurements}

Oil-in-water emulsion

$3.5 \mathrm{ml}$ of the cell free broth was vigorously shaken with $2.0 \mathrm{ml}$ of toluene for one minute on a tube vortex shaker and left undisturbed. After one hour, optical density of the oil-in-water emulsion phase was measured at $610 \mathrm{~nm}$ (Johnson et al., 1992), on a Baush and Lomb spectrophotometer, and the absorbance difference between 1 hour detection and the time zero was expressed as an unit (U).

\section{Water-in-oil emulsion}

$3.5 \mathrm{ml}$ of the cell free broth was vigorously shaken with $2.0 \mathrm{ml}$ of toluene for one minute on a tube vortex shaker and left undisturbed. After $24 \mathrm{~h}$ the height of the emulsion layer (water-in-oil) was measured and emulsification activity was expressed in cm (Cooper and Goldenberg, 1987). The activity was only evaluated for emulsion layers with small sized bubbles with a compact aspect due to its high stability.

\section{Bioremediation assays}

Non-diluted oily effluent was obtained from a margarine and soap industry at Campinas city, São Paulo State - Brazil. Bioremediation assays were carried out with both strains Pantoea agglomerans and Planococcus citreus. All the experiments were performed with non-autoclaved effluent. The assays were performed in $100 \mathrm{~mL}$ Erlenmeyer flasks and samples were collected after $0,24,48,72$ and $120 \mathrm{~h}$ of incubation at $150 \mathrm{rpm}, 30^{\circ} \mathrm{C}$. Six experiments were performed: 1a) $10 \mu \mathrm{l}$ of Pantoea agglomerans 
growth on NA medium was added to $50 \mathrm{~mL}$ effluent; 1b) $10 \mu \mathrm{l}$ of Planococcus citreus growth on YPD Agar medium was added to $50 \mathrm{~mL}$ effluent; 2) $5 \mu \mathrm{l}$ of Pantoea agglomerans and $5 \mu \mathrm{l}$ of Planococcus citreus were added simultaneously to $50 \mathrm{~mL}$ effluent; 3a) $0.25 \mathrm{~g}$ of Pantoea agglomerans biosurfactant was added to $50 \mathrm{~mL}$ effluent; 3b) $0.25 \mathrm{~g}$ of Planococcus citreus biosurfactant was added to $50 \mathrm{~mL}$ effluent; 4) 0.125 $\mathrm{g}$ of each biosurfactant was added to $50 \mathrm{~mL}$ effluent.

\section{Analysis}

The COD determination was carried out utilizing potassium dichromate as oxidant agent (Greenberg et al., 1992) in a COD reactor (Model 2000, Hach Company). The COD reduction was determined on the six-bioremediation assays at 24, 48, 72 and 120 $\mathrm{h}$ and the percentage was established by the difference among COD values in each incubation period and the value at zero time.

Total solids were measured by washing oily effluent cellular mass in acetone:hexane solution $(3: 1 \mathrm{v} / \mathrm{v})$ and drying at $105^{\circ} \mathrm{C}$ during $24 \mathrm{~h}$ (Pruthi and Cameotra, 1997). The $\mathrm{pH}$ was determined utilizing a TECNAL digital $\mathrm{pHmeter}$.

All tests were done in duplicate and the average values are shown in results.

\section{RESULTS AND DISCUSSION}

During biosurfactant production in mineral medium with oily substrate, it was possible to observe that after $8 \mathrm{~h}$ of Pantoea agglomerans incubation, a white foam was formed on the liquid surface. The Planococcus citreus cells wrapped olive oil droplets in $12 \mathrm{~h}$ of growth forming an orange layer on medium surface.

Pantoea agglomerans presented biosurfactant activity after $48 \mathrm{~h}$ of incubation with kerosene as carbon source, producing a $2.5 \mathrm{~cm}$ stable layer of water-in-oil emulsion. The activity of oil-in-water emulsions was $0.15 \mathrm{U}$. The strain Planococcus citreus in culture broth with olive oil as carbon source produced $1.079 \mathrm{U}$ of oil-in-water emulsions activity and $0.2 \mathrm{~cm}$ of stable layer of water-in-oil emulsion activity. These results showed that the bacterial strains produced distinct biosurfactants. The main characteristic of Planococcus citreus surfactant was the formation of oil-in-water emulsions, while water-in-oil emulsions characterized Pantoea agglomerans surfactant.

The biosurfactant production of Planococcus citreus was $2.014 \mathrm{~g} / \mathrm{L}$, more than twice the Pantoea agglomerans production, which was $0.87 \mathrm{~g} / \mathrm{L}$. Since incubation was not performed in a fermenter, the biosurfactant yield of Planococcus citreus was considerable and was very similar to the yield registered by Navon-Venezia et al. (1995) for the synthetic Alasan biosurfactant $(2.35 \mathrm{~g} / \mathrm{L})$.

Figure 1 shows oily effluent COD reduction during bioremediation assays, involving the six experiments with bacteria and isolated biosurfactants.

The initial oily effluent COD value was 4400 $\mathrm{mg} / \mathrm{L}$. Bioremediation assays with the addition of bacterial strains separately furnished the best results in COD reduction. The $72 \mathrm{~h}$ incubation experiment resulted in a COD reduction of $76 \%$ with Planococcus citreus strain and $70 \%$ with Pantoea agglomerans. The COD reduction achieved with the interaction between biosurfactants that promoted the formation of both oil-in-water and water-in-oil emulsions, was over $50 \%$ in $24 \mathrm{~h}$ of incubation. According to Mulligan (2005), a new biosurfactant named BOD-Balance studied by Nakha et al. (2003) was able to reduce in $40.86 \%$ the COD of an oily pet food wastewater, during two months of digestion process. Comparing these data with the results here obtained, the biosurfactants consortium showed good results relative to COD reduction. When the biosurfactants were added to oily effluent, the best results were obtained at $24 \mathrm{~h}$ incubation, probably because emulsions stability was reduced at longer incubation periods.

When the bacterial strains were added to the effluent, a higher COD reduction was observed in relation to biosurfactant addition, probably because the biosurfactant just modified the oil drops of effluent and bacteria were able to produce the biosurfactants and biodegrade this oily material. 


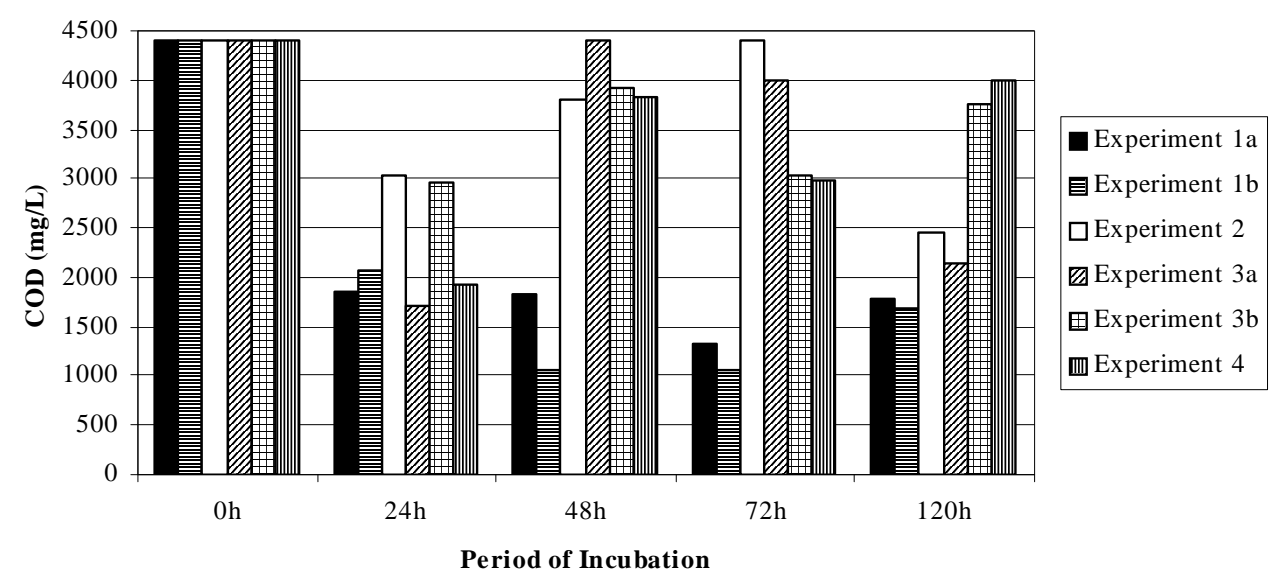

Figure 1 - Chemical Oxygen Demand Reduction on bioremediation assays.

Figure 2 shows the total solids variation in bioremediation assays (experiments $1 \mathrm{a}, 1 \mathrm{~b}$ and 2). The Planococcus citreus strain grew vigorously on oily effluent probably because vegetable oils used in the margarine and soap industry, present in the effluent, were a rich carbon source to this bacterium. The relation of COD reduction and biomass of strains simultaneously added to effluent revealed that the low growth corresponded to a low COD decreased.
This could be related to the work of Dorobantu et al. (2004) which suggested that emulsification could be associated with the surface properties of the cells, as a result of attachment to the oil-water interface by general hydrophobic interactions.

Consequently, an increase in cell number in the effluent could lead to an increase of cell-oil drop adherence, favouring the oily substrate emulsification.

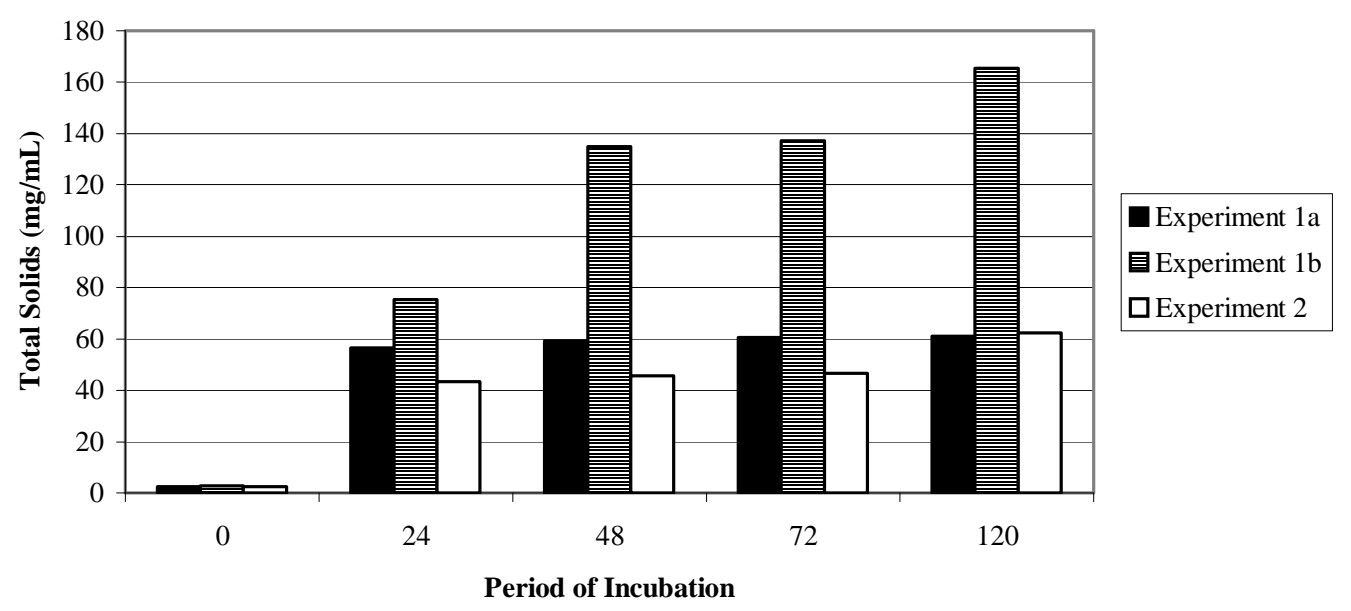

Figure 2 - Total solids variation during bioremediation assays.

Table 1 represents $\mathrm{pH}$ variation in the six experiments of bioremediation. The initial $\mathrm{pH}$ of margarine and soap industry oily effluent was 7.01 the industry corrected the final effluent before sending to the treatment plant. An initial increase in $\mathrm{pH}$ values was observed $24 \mathrm{~h}$ after the addition of biosurfactants to the oily effluent. At longer incubation periods, a slight $\mathrm{pH}$ decrease was registered relative to the initial value. When the bacteria strains were added, in experiments 1a, 1b and 2 , the $\mathrm{pH}$ was reduced in all incubation periods. The optimal $\mathrm{pH}$ for Planococcus citreus growth varied from 6.9 to 7.2 (Claus et al., 1992) and for Pantoea agglomerans from 6.8 to 7.1 (Ewing, 1986). It was probable that a $\mathrm{pH}$ correction of effluent to 7.0 would give best results on COD reduction. 
Table 1 - $\mathrm{pH}$ variation during bioremediation assays.

\begin{tabular}{ccccc}
\hline Experiments & & $\mathbf{p H}$ & & \\
\hline 1a & $\mathbf{2 4} \mathbf{h}$ & $\mathbf{4 8} \mathbf{~ h}$ & $\mathbf{7 2} \mathbf{h}$ & $\mathbf{1 2 0} \mathbf{~}$ \\
\hline 1b & 5.97 & 5.99 & 6.00 & 5.95 \\
2 & 6.37 & 6.09 & 6.14 & 6.10 \\
3a & 6.05 & 5.97 & 6.00 & 5.93 \\
3b & 7.40 & 6.98 & 6.88 & 6.79 \\
4 & 7.02 & 6.76 & 6.92 & 6.85 \\
\hline
\end{tabular}

Thus, bacterial strains Pantoea agglomerans and Planococcus citreus have potential to be directly used on oily effluent bioremediation. These results are important to promote new studies and the use of native strains for effluent treatment of Brazilian industries.

\section{ACKNOWLEDGEMENTS}

The authors acknowledge financial support from FAPESP and Instituto Costa Brasilis.

\section{RESUMO}

Duas bactérias isoladas de solo contaminado com derivados de petróleo, Pantoea agglomerans e Planococcus citreus, produzem biosurfactantes utilizando respectivamente $1.5 \%$ de querosene e óleo de oliva como únicas fontes de carbono. As bactérias e os biosurfactantes produzidos foram adicionados a um efluente oleoso obtido de uma indústria nacional de sabão e margarina. As atividades de emulsificação foram determinadas pelo aumento da absorbância das emulsões óleo em água a $610 \mathrm{~nm}$, enquanto que as emulsões do tipo água em óleo foram expressas em centímetros, pela altura do halo de espumas formado. A redução da demanda química de oxigênio (COD) mostra que as linhagens e os biosurfactantes produzidos podem ser utilizados em processos de biorremediação.

\section{REFERENCES}

Ashtaputre, A. A.; Shah A. K. (1995), Emulsifying property of a viscous exopolysaccharide from Sphingomonas paucimobilis. World Journal of Microbiology and Biotechnology, 11, 219-222.

Carrillo, P. G.; Mardaraz, S. I.; Pitta-Alvarez; Giulietti, A. M. (1996), Isolation and section of biosurfactant producing bacteria. World Journal of Microbiology and Biotechnology, 12, 82-84.

Claus, D.; Fritze, D.; Kocur, M. (1992), Genera related to the genus Bacillus - Sporolactobacillus, Sporosarcina, Planococcus, Filibacter and Caryophanon. In-The Prokaryotes, eds. A. Balows; H.G. Truper; M. Dworkin; W. Harder; K.H. Schleifer. Fischer-Verlog, New York.

Cooper, D.; Goldenberg, B.G. (1987), Surface active agents from two Bacillus species. Applied and Environmental Microbiology, 53, 224-229.

Deleu, M.; Paquot, M. (2004), From renewable vegetables resources to microorganisms: new trends in surfactants. Comptes Rendus Chimie, 7, 641-646.

Dorobantu, L. S.; Yeung, A. K. C.; Fogth, J. M.; Gray, M. R. (2004), Stabilization of oil-water emulsions by hidrophobic bacteria. Applied and Environmental Microbiology, 70 (10), 6333-6336.

Durrant, L. R. Carvalho, D. F.; Marchi, D. D. (1999), Diesel Oil: A source for the production of biosurfactants. In: Bioremediation of petroleum hydrocarbon and other organic compounds. Battelle Press, Ohio, 1, 457-462.

Ewing, W. H. (1986), Edwards and Ewing's identification of Enterobacteriaceae. Elsevier Science, New York.

Greenberg, A. E.; Clesceri, L. S.; Eaton, A. D. (1992), Standard methods for the examination of water and wastewater, 18 ed., American Public Health Association, Washington.

Holt, J. G.; Krieg, N. R.; Sneath, P. H. A.; Staley, J. T.; Williams, S. T. (1994), Bergey's Manual of Determinative Bacteriology. Williams and Wilkins, Baltimore.

Jacobucci, D. F. C.; Vasconcellos, K. C.; Matsuura, A. B.; Falcón, F. A.; Durrant, L. R. (2001), Degradation of Diesel Oil by Biosurfactant-Producing Bacterial Strains. Contaminated Soil Sediment and Water, 8 (1), 31-34.

Johnson, V.; Singh, M.; Saini, V. S.; Adhikari, D.K.; Sista, V.; Yadav, N.K. (1992), Bioemulsifier prodution by an oleaginous yeast Rhodotorula glutinis IIP-30. Biotechnology Letters, 6, 487-490.

Mulligan, C. N. (2005), Environmental applications for biosurfactants. Environmental Pollution, 133, 183198. 
Navon-Venezia, S.; Zosim, Z.; Gottlieb, A.; Legmann, R.; Carmeli, S.; Ron, E.Z.; Rosemberg, E. (1995), Alasan, a new bioemulsifier from Acinetobacter radioresistens. Applied and Environmental Microbiology, 61 (9), 3240-3244.

Pruthi, V.; Cameotra, S. S. (1997), Short Communication: Production of a biosurfactant exhibiting excellent emulsification and surface active properties by Serratia marcescens World Journal of Microbiology and Biotechnology, 13, 133-135.

Rapp, P.; Backhaus, S. (1992), Formation of extracellular lipases by filamentous fungi, yeasts, and bacteria. Enzyme and Microbial Technology, 14, 938943.
Rocha, C.; San-Blas, F.; San-Blas, G.; Vierma, L. (1992), Biosurfactant production by 2 isolates of Pseudomonas aeruginosa. World Journal of Microbiology and Biotechnology, 8, 125-128.

Von Sperlins, M. (1996), Introdução à qualidade das águas e ao tratamento de esgotos. 2 ed. Universidade Federal de Minas Gerais, Belo Horizonte.
Received: May 03, 2006; Revised: January 07, 2007; Accepted: November 21, 2008. 